\title{
DINAMIKA HUKUM DAN PERKEMBANGAN PERBANKAN ISLAM DI INDONESIA
}

\author{
Abdul Mujib \\ UIN Sunan Kalijaga Yogyakarta \\ e-mail: mujib_bima@yahoo.co.id
}

\begin{abstract}
Almost all countries in the world including Indonesia give serious attention to the existence of Islamic banking that using religion approach in all activities and services. Institutional development it should be followed by the availability of legal basis, which is an established and clear. During the six years of its inception, the Islamic banking law stands with a very limited law basis, although the limitations of regulations have been describing aspects of sharia in Islamic banking for sure. The improvement of law is done by replacing Law No. 7 of 1992 by the Law No. 10 of 1998. This law has explicitly mention sharia aspects of Islamic banking, however Islamic banking regulation still governed together with conventional banking. The birth of Law 21 of 2008 became an important change for the development of Islamic banking. This law has given limits and a clear boundary line between Islamic banking and conventional banking in various aspects. The development of Islamic banking regulation are gaining its momentum with the enactment of Law No. 21 of 2008 concerning Islamic Banking. The strategic value of this law is increasingly opening up opportunities and legal certainty to accelerate the development of Islamic banks in the future.
\end{abstract}

[]

Hampir seluruh negara di dunia memberikan perhatian serius terhadap keberadaan perbankan syari'ah yang menggunakan pendekatan agama dalam seluruh aktifitas dan layanannya, tidak terkecuali Indonesia. Perkembangan kelembagaan sudah semestinya diikuti oleh tersedianya landasan hukum yang mapan dan terarah. Selama enam tahun awal, perbankan syari'ah berdiri dengan payung hukum yang sangat terbatas, meski kerbatasan pengaturan tersebut telah mendiskripsikan secara pasti aspek syari'ah dari perbankan syari'ah. Perbaikan dan penyempurnaan aturan hukum dilakukan dengan mengganti UU No. 7 Tahun 1992 dengan UU No. 10 Tahun 1998. UU ini secara eksplisit telah menyebutkan aspek syari'ah dari perbankan syari'ah, namun namun pengaturan perbankan syari'ah masih bersama-sama dengan perbankan konvensional. Lahirnya UU No. 21 Tahun 2008 menjadi satu perubahan penting bagi perkembangan perbankan syari'ah. Undang-undang ini telah memberikan batasan dan garis pembatas yang jelas antara perbankan syari'ah dan perbankan konvensional dalam berbagai aspek. Perkembangan pengaturan perbankan syari'ah mendapatkan momentumnya dengan disahkannya UU No. 21 Tahun 2008 tentang Perbankan Syari'ah. Nilai strategis dari undang-undang ini adalah semakin terbukanya peluang dan kepastian hukum untuk mendorong akselerasi perkembangan banksyari'ah di masa yang akan datang.

Keywords: perbankan syari’ah, bank konvensional, UU No. 7 Tahun 1992.

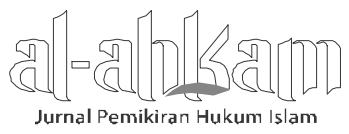


Abdul Mujib

\section{Pendahuluan}

Perbankan syari'ah menerapkan sistem bebas bunga (interest free) secara global berkembang dengan pesat, tarik ulur dalam pendiriannya juga ikut memberikan warna tersendiri dalam eksistensinya di berbagai negara. Indonesia menjadi salah satu negara yang ikut mengembangkan sstem perbankan ini menjadi salah satu bentuk perbankan yang diakui keberadaanya.

Keberadaan perbankan syari'ah pada tahap awal tidak serta merta dapat diterima dengan baik oleh publik, khususnya dalam hal hukum perbankan syari'ah. Aspek pengaturan dan regulasi dari pemerintah menjadi salah satu faktor yang dapat mendukung perkembangan perbankan syari'ah di Indonesia.

Pada masa awal pendirian perbankan syari'ah hingga saat ini sudah beberapa kali dilakukan upaya pembangunan hukum untuk mendukung keberadaan lembaga keuangan yang berbasis syari'ah ini. Paling tidak tercatat tiga kali perubahan dari hukum perbankan syari'ah, yaitu UU No. 7 Tahun 1992, UU No 10 Tahun 1998, dan yang terakhir adalah UU No. 21 Tahun 2008. Masing-masing perubahan hukum tersebut juga ikut mewarnai perkembangan perbankan syari'ah, baik secara kelembagaan maupun perolehan Dana Pihak Ketiga (DPK). Dalam kerangka pemikiran inilah tulisan ini menjadi penting. Selain mendiskripsikan secara detail perkembangan hukum perbankan syari'ah, tulisan ini juga menganalisis korelasi antara hukum dan perkembangan perbankan syari'ah di Indonesia.

\section{Sistem Perbankan Syari'ah di Indonesia}

Istilah perbankan syari'ah ${ }^{1}$ merupakan fenomena baru dalam dunia ekonomi modern, kemunculannya seiring dengan upaya gencar yang dilakukan oleh pakar Islam dalam mendukung ekonomi Islam yang diyakini akan mampu mengganti dan memperbaiki sistem ekonomi konvensional ${ }^{2}$ yang berbasis pada bunga.

\footnotetext{
1Secara akademik, istilah Islam dengan syari'ah mempunyai pengertian yang berbeda. Namun secara teknis untuk penyebutan bank Islam dan bank syari'ah mempunyai pengertian yang sama. Lihat Warkum Sumitro, Azas-azas Perbankan Islam dan Lembaga-lembaga Terkait Jakarta: Grafindo Persada, 2004), h. 5. "Bank Islam adalah lembaga keuangan yang usaha pokoknya memberikan kredit dan jasa-jasa dalam lalu lintas pembayaran serta peredaran uang yang pengoperasiannya disesuaikan dengan prinsip-prinsip syari'at Islam". Lihat: H. A. Hafizh Dasuki et.al, Ensiklopedi Islam, Jilid I (Jakarta: Ichtiar Baru Van Hoeve, 1994), h. 231. Prinsip syari'ah yang dimaksud mengacu pada fatwa DSN-MUI, lihat Kompilasi Hukum Ekonomi Syari'ah (KHESy).

${ }^{2}$ Konvensional di sini dimaksudkan sebagai lawan dari syari'ah, dengan kata lain bahwa konvensional adalah sistem yang biasa atau umum berjalan. Berasal dari bahasa Inggris convention yang 
Perbankan syari'ah menerapkan sistem bebas bunga (interest free) dalam operasionalnya, dan oleh karena itu rumusan yang tepat untuk mendefinisikan perbankan syari'ah adalah bank yang beroperasi sesuai dengan prinsip-prinsip syariat Islam, dengan mengacu kepada al-Qur'an dan sunnah sebagai landasan dasar hukum dan pembentukannya. ${ }^{3}$

Gagasan untuk mendirikan lembaga keuangan perbankan syari'ah terus diawali pada tahun 1941-an. Pakistan dan Malaysia merupakan dua negara yang telah memulai gagasan awal pendirian bank syari'ah dengan mengelola dana jamaah haji secara non konvensional, ${ }^{4}$ yaitu dengan profit and loss sharing. Hanya saja yang telah dirintis kedua negara tersebut belum diwujudkan dalam institusi perbankan.

Gagasan awal bank syari'ah pertama kali muncul di Mesir. Perintis pendirian bank ini adalah Ahmad El-Najjar, gagasan ini mengambil bentuk bank simpanan yang berbasis profit sharing di Kota Mit Ghamr pada tahun $1963 .{ }^{5}$ Eksperimen ini berlangsung hingga tahun 1967. Lembaga ini, tidak memungut maupun menerima bunga, sebagian besar programnya adalah menanamkan investasi pada usaha perdagangan dan industri dalam bentuk partnership, serta membagi keuntungan dengan para penabung dan nasabah bank lainnya. Akan tetapi secara prinsip pendirian bank ini tidak menggunakan identitas Islam atau syari'ah, karena ada kekhawatiran diklaim sebagai gerakan fundamentalis. Pada tahun 1971 di Mesir juga berdiri Nasir Social Bank. Bank ini didirikan sebagai bank komersial pertama yang bebas bunga. Kendati demikian dalam akta pendiriannya bank ini tidak menyebutkan secara eksplisit merujuk kepada agama maupun syari'ah Islam. ${ }^{6}$

berarti yang biasa atau lazim. Lihat John M. Echols, Kamus Inggris Indonesia an English-Indonesia Dictionary (Jakarta: Gramedia Pustaka Utama, 2002), h. 145. Lihat pula penggunaan istilah ini dalam naskah Undang-Undang No 21 Tahun 2008 tentang perbankan syari'ah dan Undang-Undang No 10 Tahun 1998 tentang perbankan dan juga digunakan dalam beberapa literatur dalam dan luar negeri. Istilah ini dipakai secara umum untuk memberikan istilah pembeda bank yang tidak menganut sistem syari'ah.

${ }^{3}$ Lihat Frank E. Vogel and Samuel L. Hayes, Islamic Law And Finance Religion, Risk, and Return (Netherlands: Kluwer Law International, 1998), h. 1. Lihat juga Ibrahim Warde, Islamic Finance in The Global Economy (Edinburgh: Edinburgh University Press, 2000), h. 5. Lihat pula Undang-undang No. 21 Tahun 2008.

${ }^{4}$ Ibid, h. 73.

${ }^{5}$ Adiwarman A. Karim, Bank Islam Analisis Fikih dan Keuangan (Jakarta: Raja Grafindo Persada, 2007), h. 23.

6Frank E. Vogel and Samuel L. Hayes, Islamic Law And Finance..., h. 12.

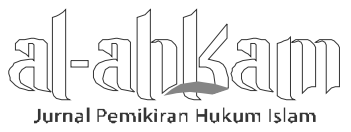

Volume 23, Nomor 2, Oktober 2013 
Abdul Mujib

Islamic Development Bank (IDB) ${ }^{7}$ kemudian berdiri pada tahun 1973 disponsori oleh negara-negara yang tergabung dalam Organisasi Konferensi Islam, walaupun IDB adalah bank antar pemerintah yang bertujuan untuk menyediakan dana untuk proyek pembangunan di negara-negara anggotanya. IDB juga menyediakan jasa finansial berbasis free and profit sharing untuk negara-negara tersebut dan secara eksplisit menyatakan diri berdasar pada syari'ah Islam.

Setelah lahirnya IDB di beberapa negara, sejumlah bank berbasis Islam kemudian muncul. Beberapa berdiri di Timur Tengah, seperti Dubai Isl,amic Bank (1975), Faisal Islamic Bank of Sudan (1977), Faisal Islamic Bank of Egypt (1977) serta Bahrain Islamic Bank (1979). Di Asia Pasifik, Phillipine Amanah Bank didirikan tahun 1973 berdasarkan dekrit presiden, dan di Malaysia tahun 1983 berdiri Muslim Pilgrims Savings Corporation yang bertujuan membantu mereka yang ingin menabung untuk menunaikan ibadah haji. ${ }^{8}$

Bank syari'ah di Indonesia muncul untuk pertama kalinya pada tahun 1992 yaitu ditandai dengan berdirinya Bank Muamalat Indonesia (BMI). Pendirian lembaga ini diprakarsai oleh Majelis Ulama Indonesia (MUI) ${ }^{9}$ dan pemerintah.

\footnotetext{
7Islamic Development Bank (IDB) atau Bank Pembangunan Islam, merupakan lembaga keuangan multilateral yang didirikan pada tahun 1973 (1392 H) oleh Organisasi Konferensi Islam (OKI) untuk meningkatkan kualitas kehidupan sosial ekonomi negara anggota dan masyarakat Muslim di negara bukan anggota berlandaskan prinsip-prinsip Islami/syariah. Visi IDB adalah menjadi leader dalam membantu perkembangan pembangunan sosial ekonomi negara anggota dan masyarakat Muslim yang tinggal bukan di negara anggota sesuai dengan prinsip Islami/syari'ah. IDB Mendukung pembangunan manusia secara komprehensif dengan fokus pada pengurangan kemiskinan, peningkatan kesehatan, serta peningkatan pengelolaan dan kesejahteraan rakyat. Fungsi utama IDB adalah memberikan pembiayaan berdasarkan prinsip-prinsip Islami untuk pembangunan ekonomi dan sosial, terutama untuk proyek-proyek yang dapat meningkatkan kualitas hidup masyarakat. Bank Pembangunan Islam (IDB) dalam kapasitasnya sebagai lembaga keuangan dan pembangunan multilateral memiliki empat lembaga dalam satu kelompok (group) yang masing-masing mempunyai peran dan fungsi sendirisendiri, keempat lembaga tersebut adalah: Islamic Research and Training Institute (IRTI), Islamic Corporation for the Development of the Private Sector (ICD), Islamic Corporation for the Insurance of Investment and Export Credit (ICIEC), Islamic Trade Finance Corporation (ITFC) Produk-produk yang saat ini dikelola oleh IDB adalah sebagai berikut: Loan, Leasing, Installment Sale, Istisna'a, Equity Participation, Lines of Financing. http://www.idbindonesia. co.id.
}

${ }^{8}$ Muhammad Firdaus NH, Briefcase Book Edukasi Profesional Syari'ah Konsep dan Implementasi Bank Syari'ah (Jakarta: Renaisan, 2005), h. 20-24.

9Majelis Ulama Indonesia adalah lembaga "keulamaan" non pemerintah yang independen didirikan pada tanggal 26 Juli 1975 di Jakarta. Tujuan pendirian lembaga ini adalah untuk menghimpun pandapat dan pikiran-pikiran ulama Indonesia, dalam rangka menciptakan masyarakat yang aman, adil dan makmur. Di samping itu lembaga ini memiliki fungsi sebagai lembaga yang memberikan fatwa dan pendapat serta nasehat bagi pemerintah dan masyarakat tentang agama. Lihat Harun Nasution (ed), Ensiklopedi Islam (Jakarta: Departemen Agama, 1988), h. 555.

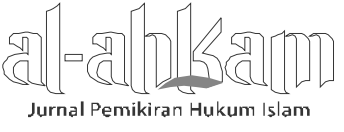


Proses pendiriannya pun mendapatkan dukungan yang kuat dari Ikatan Cendekiawan Muslim Indonesia (ICMI) ${ }^{10}$ dan beberapa pengusaha Muslim.. ${ }^{11}$

Bank pada umumnya memiliki peran yang cukup signifikan dalam sistem keuangan sebuah Negara, demikian juga dengan keberadaan bank syari'ah. Aktivitas intermediasi keuangan oleh bank sangat mempengaruhi pertumbuhan ekonomi dari berbagai tujuan sosial ekonominya. Aktivitas intermediasi keuangan bank adalah proses pemberian dana dari kelompok masyarakat yang memiliki kelebihan dana (surplus unit), untuk selanjutnya didistribusikan kembali kepada kelompok masyarakat yang memiliki kekuarangan dana (deficit unit). ${ }^{12}$

Bank syari'ah sebagaimana bank konvensional memiliki peranan yang sama sebagai lalu lintas keuangan dan memobilisasi dana dari masyarakat bagi peningkatan kesejahteraan, sebagaimana yang di amanatkan oleh UU No. 10 Tahun 1998. Bank syari'ah secara bersama-sama dengan bank konvensional secara sinergis mendukung mobilisasi dana masyarakat secara lebih luas untuk meningkatkan kemampuan pembiayaan bagi sektor-sektor perekonomian nasional.

Karakteristik sistem bank syari'ah yang beroperasi berdasarkan prinsip bagi hasil memberikan warna sistem bank yang saling menguntungkan bagi masyarakat dan bank, serta menonjolkan aspek keadilan dalam bertransaksi, investasi yang beretika, mengedepankan nilai-nilai kebersamaan dan persaudaraan dalam berproduksi, dan menghindari kegiatan spekulatif dalam bertransaksi keuangan. Dengan menyediakan beragam produk serta layanan jasa bank yang beragam dengan skema keuangan yang lebih bervariatif, bank syari'ah menjadi sistem bank yang kredibel dan dapat dinimati oleh seluruh golongan masyarakat Indonesia tanpa terkecuali.

\section{Hukum Perbankan Syari'ah di Indonesia}

Bank merupakan nadi sistem keuangan pada setiap negara di dunia. Bank juga menjadi bagian yang tak terpisahkan dari pasar uang. Pasar uang menjadi salah

\footnotetext{
${ }^{10} \mathrm{Ikatan}$ Cendekiawan Muslim Indonesia (ICMI) adalah lembaga sosial yag didirikan untuk mewadahi para pakar dan cendekiawan Muslim secara nasional. Didirikan untuk pertama kalinya di Malang pada desember 1990. Peran strategisnya adalah sebagai agen perubahan, inspirator, motor penggerak dan sekaligus sebagai katalisator bagi kemajuan ummat Islam dan segenap bangsa Indonesia.

${ }_{11}^{11}$ Adiwarman A. Karim, Bank Islam Analisis Fikih..., h. 25. Lihat juga Angelo M. Venardos, Islamic Banking and Finance In South-East Asia; Its Development and Future (Singapura: World Scientific Publishing, 2005), h. 7.

12Julius R. Ratumaelisa, Bank dan Lembaga Keuangan Lainnya (Jakarta: Salemba Empat, 2012), h. 41.

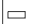

Jurnal Pemikiran Hukum Islam

Volume 23, Nomor 2, Oktober 2013
} 
satu instrumen penting dalam aktifitas ekonomi global, di mana pada pasar uang berfungsi sebagai tempat pertemuan abstrak antara pemilik dana jangka pendek untuk menawarkan kepada calon pemakai yang membutuhkannya, baik secara langsung maupun melalui perantara.

Posisi perantara dalam pasar uang dapat diperankan salah satunya oleh bank. Pada lembaga perbankan, individu atau organisasi yang mempunyai kelebihan dana jangka pendek bertemu dengan individu yang memerlukan dana. Dengan intensitas hubungan pihak-pihak dalam transaksi perbankan, maka aspek hukum dari kelembagaan menjadi penting untuk menghindari terjadinya kesalahan dalam pengelolaan dan pendistribusian dana dalam masyarakat. Pemerintah sebagai pemegang kendali regulasi dan pengawasan telah melakukan berbagai upaya untuk memberikan rasa aman bagi masyarakat dalam berhubungan dengan lembaga keuangan. Lembaga keuangan syari'ah khususnya perbankan syari'ah telah mendapatkan pengaturan melalui undang-undang, baik secara langsung maupun secara tidak langsung. Berikut ini adalah beberapa landasan hukum dalam penyelenggaraan lembaga keuangan syari'ah berupa bankyang ada di Indonesia.

\section{UU No. 7 Tahun 1992}

Berdirinya Bank Muamalat Indonesia menjadi babak baru dunia perbankan syari'ah di Indonesia. Namun demikian masih memiliki pekerjaan rumah yang banyak, khususnya terkait dengan aspek hukum dan prospek pengembangan sistem perbankan syari'ah. Bank Muamalat Indonesia sebagai bank syari'ah yang kali pertama didirikan, pada saat pendiriannya belum ada landasan hukum khusus yang dapat mengiringi perkembangan dan kegiatannya. Peraturan yang digunakan adalah UU No. 7/1992 tentang Perbankan yang memuat ketentuan secara implisit yang memperbolehkan pengelolaan perbankan dengan prinsip bagi hasil, serta dengan didukung oleh Peraturan Pemerintah (PP) No 72 Tahun 1992 tentang Bank Berdasarkan Prinsip Bagi Hasil. ${ }^{13}$

Pada prinsipnya undang-undang ini tidak mengatur tentang bank syari'ah, akan tetapi hanya mengatur tentang kemungkinan penyelenggaraan bank dengan prinsip bagi hasil. Dengan kata lain bahwa undang-undang ini secara eksplisit tidak menyebutkan kemungkinan mendirikan bank dengan prinsip syari'ah. Hanya saja

${ }^{13}$ Abdul Ghofur Anshori, Perbankan Syari'ah di Indonsia (Yogyakarta: Gajah Mada University Press, 2007), h. 30.

172 || Volume 23, Nomor 2, Oktober 2013

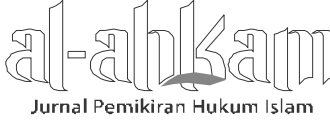


ada celah yang mungkin dipergunakan untuk dapat mewujudkan bank syari'ah, yaitu pada Pasal 1 ayat 12 tentang kemungkinan menyelenggarakan kegiatan dengan mengunakan prinsip bagi hasil. ${ }^{14}$

Prinsip perbankan dengan menggunakan prinsip profit and loss sharing sebagaimana yang dimaksudkan dalam pasal tersebut dimanfaatkan oleh para inisiator untuk mendirikan bank syari'ah pertama. Atas dasar landasan hukum ini dan melihat kenyataan tuntutan akan keberadaaan lembaga keuangan bank dengan prinsip syari'ah, maka pemerintah menerbitkan PP No. 72 tahun 1992 tentang Bank Berdasarkan Prinsip Bagi Hasil. Peraturan Pemerintah tersebut sudah secara tegas menyatakan dan mengakui adanya prinsip syari'ah. Peraturan ini mengklaim bahwa yang dimaksud dengan prinsip bagi hasil dalam UU No. 7 Tahun 1992 adalah prinsip bagi hasil syari'ah. ${ }^{15}$

Keberadaan bank syari'ah ini sebenarnya juga telah diatur dalam undangundang tersebut pada pasal 13 ayat (c) yang menyatakan bahwa salah satu usaha Bank Perkreditan Rakyat (BPR) menyediakan pembiayaan bagi nasabah berdasarkan prinsip bagi hasil sesuai dengan ketentuan yang ditetapkan dalam peraturan pemerintah. Berdasarkan pasal tersebut, pemerintah pada tanggal 30 Oktober 1992 mengeluarkan PP No 72 Tahun 1992 tentang bank berdasarkan prinsip bagi hasil dan diundangkan pada tanggal 30 Oktober 1992 dalam Lembaran Negara Republik Indonesia No. 119 tahun 1992.

Pada tahap awal perkembangannya bank syari'ah di Indonesia berjalan dengan menggunakan kerangka peraturan bank konvensional. Namun demikian, dalam perjalanannya, beberapa instrumen seperti perizinan untuk mendirikan bank dan membuka kantor, instrumen pasar antar bank, perangkat penghubung dengan otoritas moneter, dan sistem pembayaran, telah mulai dikembangkan.

Dalam menjalankan perannya bank syari'ah berlandaskan pada UU Perbankan No. 7 Tahun 1992 dan PP No. 72 Tahun 1992 tentang Bank Berdasarkan Prinsip

\footnotetext{
${ }^{14}$ Lihat UU No. 7 Tahun 1992, lihat juga Umar Faruq, "Sejarah Perkembangan Hukum Bank Syari'ah di Indonesia “ diakses tanggal 12 Agustus 2007.

15 Lihat pasal 2 PP No. 72 Tahun 1992; Prinsip bagi hasil sebagaimana dimaksud dalam Pasal 1 ayat (1) adalah prinsip bagi hasil berdasarkan syariah yang digunakan oleh bank berdasarkan prinsip bagi hasil dalam: a) menetapkan imbalan yang akan diberikan kepada masyarakat sehubungan dengan penggunaan/pemanfaatan dana masyarakat yang dipercayakan kepadanya; b) menetapkan imbalan yang akan diterima sehubungan dengan penyediaan dana kepada masyarakat dalam bentuk pembiayaan baik untuk keperluan investasi maupun modal kerja; c) menetapkan imbalan sehubungan dengan kegiatan usaha lainnya yang lazim dilakukan oleh bank dengan prinsip bagi hasil.
}

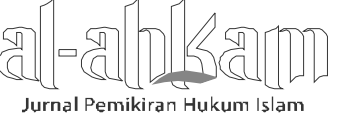


Bagi Hasil yang kemudian dijabarkan dalam S.E.B.I. No. 25/4/BPPP (SEBI) tangal 29 Februari 1993. SEBI tersebut pada pokoknya menetapkan hak-hak antara lain: Pertama, bank berdasarkan bagi hasil adalah bank umum dan Bank Perkreditan Rakyat yang dilakukan usaha semata-mata berdasarkan prinsip bagi hasil. Kedua, prinsip bagi hasil yang dimaksud adalah prinsip bagi hasil yang berdasarkan syari'ah. Ketiga, bank berdasarkan prinsip bagi hasil wajib memiliki Dewan Pengawas Syari'ah. Keempat, bank umum atau Bank Perkreditan Rakyat yang kegiatan usahanya semata-mata berdasarkan prinsip bagi hasil tidak diperkenankan melakukan usaha yang tidak berdasarkan prinsip bagi hasil. Sebaliknya, bank umum atau Bank Perkreditan Rakyat yang kegiatan usahanya tidak berdasarkan kepada prinsip bagi hasil tidak diperkenankan melakukan kegiatan usaha berdasarkan prinsip bagi hasil.

Seiring dengan peningkatan layanan bank syari'ah pada periode ini, ada beberapa hal yang menjadi pokok persoalan yang ikut mempengaruhi perkembangan infrastruktur bank syari'ah di Indonesia. Beberapa pokok persoalan tersebut adalah sebagai berikut: pertama, regulasi yang melingkupi lahir dan beroperasinya bank syari'ah belum seratus persen dapat mengakomodir berbagai bentuk perjanjian yang menjadi bisnis utama dari bank syari'ah. Salah satu contohnya adalah, bahwa prinsip pengelolaan dana pihak ketiga pada bank syari'ah menggunakan perjanjianperjanjian khusus seperti kerja sama mudarabah dan musyarakah. Kedua bentuk perjanjian tersebut mengharuskan bank untuk melakukan investasi pada pihak lain dan ini bertentangan dengan tugas pokok bank. ${ }^{16}$

Kedua, regulasi bank syari'ah masih belum spesifik, hingga saat pembukaan bank syari'ah pada periode ini, Undang-undang yang mengatur perbankan syari'ah masih bersifat hasil interpretasi hukum dari UU No. 7 Tahun 1992 dan hanya didukung oleh Peraturan Pemerintah No. 72 Tahun 1992 tentang bank dengan prinsip bagi hasil.

Ketiga, transaksi murabahah dalam sistem bank syari'ah merupakan perjanjian pembiayaan yang mengambil bentuk transaksi jual beli dengan cicilan di mana harga barang harus telah terlunasi ketika barang diserahkan. Dalam prakteknya bank syari'ah seharusnya juga dapat melakukan leasing yang menurut Undang-Undang Bank tidak boleh dilakukan oleh bank.

16Lihat: Pasal 6 dan 7 UU No 7 Tahun 1992 tentang Bank. 
Periode ini adalah periode awal pembangunan perbankan syari'ah di Indonesia, kendati perkembangannya tidak terlalu menggembirakan. Namun keberadaan pengaturan ini sudah cukup sebagai fondasi dasar perbankan syari'ah Indonesia dan dapat sedikit meredam pertentangan publik terkait dengan masalah bunga bank serta dapat memberikan alternatif institusi bagi beberapa kelompok masyarakat Muslim Indonesia.

\section{UU No. 10 Tahun 1998}

Beberapa tahun perbankan syari'ah beroperasi di Indonesia, dan mempertimbangkan akses dari masyarakat serta untuk ikut mendorong lahirnya institusi keuangan syari'ah yang baru, maka dilakukanlah perubahan terhadap UU No. 7 Tahun 1992 tentang Perbankan dengan UU No. 10 Tahun 1998. Kehadiran UU No. 10 Tahun 1998, secara otomatis juga menghapus Peraturan Pemerintah No 72 Tahun 1992 tentang penyelenggaraan perbankan dengan prinsip bagi hasil.

UU No. 10 Tahun 1998 sebagai pengganti UU No. 7 Tahun 1992 tentang perbankan ini dianggap lebih komprehensif bagi pengembangan perbankan syari'ah, karena hadir tepat setelah krisis moneter melanda Indonesia. Kondisi ini ikut memberikan pengaruh dalam catatan perkembangan dunia perbankan syari'ah di Indonesia.

Setelah pemberlakuan undang-undang ini perbankan syari'ah Indonesia memasuki periode perkembangan yang cukup signifikan. Pada periode ini eksistensi perbankan syari'ah semakin tegas dalam hal legalitas. Hal ini dapat ditemukan dalam determinan yang disampaikan oleh UU No. 10 Pasal 1 ayat 13 bahwa prinsip syari'ah adalah aturan perjanjian berdasarkan hukum Islam antara bank dengan pihak lain untuk menyimpan dana dan atau pembiayaan kegiatan usaha, atau kegiatan lainnya yang dinyatakan sesuai dengan syari'ah.

Di samping itu, UU No. 10 Tahun 1998 juga memberikan peluang kepada bank yang beroperasi secara konvensional untuk menyelenggarakan kegiatan usaha berdasarkan prinsip syari'ah. Dengan demikian pada bank yang beroperasi dengan prinsip konvensional dapat membuka pelayanan syari'ah secara dual banking system. ${ }^{17}$

\footnotetext{
${ }^{17}$ Pasal 1 Ayat 3 dan 4 UU No. 10 Tahun 1998 tentang Perbankan. Lihat juga Muhammad Syafíi Antonio, Bank Syari'ah: Dari Teori ke Praktik (Jakarta: Gema Insani Press, 2001), h. 23. Lihat juga Muhammad, Manajemen Bank..., h.75.
} 
Abdul Mujib

Ketegasan aturan tersebut masih diperkuat dengan diterbitkannya UU No. 23 tahun1999, di mana Bank Indonesia bertanggung jawab terhadap pengaturan dan pengawasan perbankan termasuk bank syari'ah. Bank Indonesia berwenang untuk menetapkan kebijakan moneter berdasarkan prinsip syari'ah.

\section{UU No. 21 Tahun 2008}

Pada periode awal kelahiran Bank Syari'ah di Indonesia tahun 1992. Hingga tahun 1998, hanya ada satu bank syari'ah beroperasi di Indonesia. Hal itu disebabkan dari tahun 1992 hingga 1998, sistem perundangan Indonesia tidak mengenal adanya sistem perbankan syari'ah, namun hanya mengenal prinsip bagi hasil dalam usaha perbankan seperti tercermin pada UU No.7 Tahun 1992 yang hanya menguraikan secara sepintas pasal-pasal tentang jenis dan usaha bank. Setelah keluarnya UU No. 10 Tahun 1998 tentang perbankan yang menggantikan UU No. 7 Tahun 1992, dan mengakomodir peraturan tentang bank syari'ah, serta diperkuat oleh UU No. 23 Tahun 1999 tentang Bank Indonesia, barulah lahir bank syari'ah lain dan berkembang dengan pesat.

UU No. 10 Tahun 1998 telah mengakomodir peraturan bank syari'ah, namun belum mengatur ketentuan perbankan syari'ah pada pasal-pasal khusus. Pada Undang-undang tesebut ketentuan bank syari'ah baru diatur sebatas mendefinisikan pembiayaan berdasarkan prinsip syari'ah dan jenis-jenis prinsip syari'ah yang digunakan pada perbankan. Undang-undang tersebut juga mengubah masingmasing satu ayat pada pasal 6 dan 7 yang berkaitan dengan pembiayaan bagi hasil, serta pasal 13 yang berkaitan dengan usaha Bank Perkreditan Rakyat. Dengan demikian, sebelum disahkannya UU Perbankan Syari'ah oleh DPR-RI, lembaga dan operasional bank syari'ah di Indonesia belum memiliki payung undang-undang tersendiri.

Kehadiran UU No. 21 Tahun 2008 tentang Perbankan Syari'ah membawa angin baru bagi industri keuangan syari'ah di Indonesia. Pada periode ini perbankan syari'ah Indonesia telah memiliki pengaturan yang terpisah dengan perbankan konvensional. Kalau pada pengaturan sebelumnya perbankan syari'ah masih berada dalam satu pengaturan dan sangat terbatas, yaitu dalam UU No. 7 Tahun 1992 dan UU No. 10 Tahun 1998, UU No 21 Tahun 2008 memberikan pengaturan yang cukup kompleks, tidak hanya penyebutkan aspek syari'ah dalam sistem perbankan syari'ah, namun lebih jauh dari itu adalah seluruh aspek yang terkait dengan transaksi keuangan pada perbankan syari'ah.

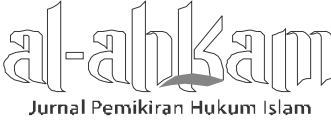


UU No. 21 Tahun 2008 memberikan peluang untuk pembukaan bank umum syari'ah yang baru dan/atau konversi dari konvensional menjadi syari'ah, demikian pula sebaliknya atau melalui proses akuisisi (Pasal 5 ayat 7 dan Pasal 17 ayat 2). Di samping itu pengaturan ini juga dapat mempercepat perkembangan kelembagaan dengan memberikan kesempatan dan peluang Warga Negara Asing atau Badan Hukum Asing dalam kemitraan untuk mendirikan dan/atau memiliki bank umum syari'ah (Pasal 9 ayat 1 butir b).

Perbankan syari'ah melalui pengaturan baru ini sudah sangat berbeda dengan perbankan konvensional terutama terkait dengan keragaman produk serta jasa layanan yang diberikan. Produk dan jasa layanan yang diberikan oleh perbankan syari'ah tidak dimiliki oleh perbankan konvensional. Bahkan perbankan syari'ah melalui pengaturan ini tidak saja memiliki layanan perbankan komersial namun juga layanan finance company, dan merchant bank. Di samping layanan-layanan komersial perbankan syari'ah juga memiliki layanan yang khas yaitu layanan sosial dalam bentuk Lembaga Baitul Mal, yaitu menerima dan menghimpun serta mendistribusikan dana yang berasal dari zakat, infak, sedekah, hibah, atau dana sosial lainnya.

Kompleksitas pengaturan UU No. 21 Tahun 2008 ini diperkuat dengan masuknya Pasal 55 tentang penyelesain sengketa yang timbul dari transaksi perbankan syari'ah. Pasal ini secara tegas menyebutkan wilayah kompetensi penyelesaian sengketa, dimana Peradilan Agama menjadi mahkamah yang dapat menyelesaikan seluruh sengketa dan perselisihan sebagai akibat dari transaksi perbankan syari'ah.

\section{Perkembangan Perbankan Syari'ah di Indonesia}

Dinamika hukum perbankan syari'ah di Indonesia telah mengantarkan perkembangan yang cukup signifikan bagi kelembagaan perbankan syariah. Perubahan yang terjadi dari UU No. 7 Tahun 1992 menjadi UU No. 10 Tahun 1998 membawa perubahan yang cukup signifikan. Sebagaimana bisa terlihat dari tingkat perkembangan bank syari'ah dalam beberapa tahun terakhir yang menunjukkan pertumbuhan yang mengesankan, baik dari volume usaha, jumlah jaringan kantor maupun performance. Sebagai ilustrasi. Perkembangan bank syari'ah yang pada tahun sebelumnya hanya ada 112 kantor, pada Agustus 2003 jumlah kantor bank syari'ah sudah menjadi 188 kantor. Sedangkan dari sudut volume, usaha transaksi bank syari'ah terus meningkat dari Rp. 1,8 triliun pada Desember 2000 menjadi Rp. 6,2 triliun pada Agustus 2003. 
Abdul Mujib

Di samping performace bank syari'ah yang berada di atas rata-rata nasional, kemajuan bank syari'ah juga tercermin dari financing deposit ratio (FDR) yang mencapai 108,03 persen pada Agustus 2003 dengan tingkat kredit macet yang cukup kecil, 3,91 persen. Hal yang paling menarik dan patut menjadi perhatian sekaligus kajian adalah nilai FDR bank syari'ah ini, ternyata jauh lebih baik dari FDR bank konvensional yang pada Agustus 2002 baru mencapai 46,47 persen. Data ini menunjukkan produktivitas bank syari'ah dalam menyalurkan pembiayaan, jauh lebih baik dibandingkan bank konvensional.

UU No. 21 Tahun 2008 tentang Perbankan Syari'ah membuka kesempatan lebih besar untuk mendorong akselerasi perkembangan bank syari'ah ke depan. Hingga saat ini, menurut statistik Bank Indonesia pertumbuhan jaringan perbankan syari'ah sudah sangat menggembirakan. Selengkapnya dapat dilihat dari table di bawah ini:

Tabel 1.

Indonesian Islamic Network 2013

\begin{tabular}{lrrrr}
\hline & Juni & Juli & Agustus & September \\
\hline Bank Umum Syari'ah & 11 & 11 & 11 & 11 \\
$\quad$ Jumlah Bank & 1.877 & 1.882 & 1.920 & 1.937 \\
$\quad$ Jumlah Kantor & & & & \\
$\begin{array}{l}\text { Unit Usaha Syari'ah } \\
\quad \text { Jumlah Bank Umum } \\
\quad \text { Konvensional yang memiliki } \\
\quad \text { Unit Usaha Syari'ah (UUS) }\end{array}$ & 24 & 24 & 23 & 23 \\
$\quad$ Jumlah Kantor & 543 & 549 & 553 & 558 \\
\hline$\quad$ Total Kantor & 1.912 & 2.456 & 2.507 & 2.529 \\
\hline
\end{tabular}

Tabel tersebut menggambarkan perkembangan kelembagaan bank syari'ah Indonesia yang telah berkembang dengan menjangkau hampir seluruh kota besar di Indonesia. Perkembangan kelembagaan selengkapnya dapat dilihat dari statistik jaringan kantor individual dari bank syari'ah Indonesia berikut ini:

18Diolah dari Statistik Bank Syariah September 2013, Otoritas Jasa Keuangan (OJK) www/ojkgov.id.

178 || Volume 23, Nomor 2, Oktober 2013

Jurnal Pemikiran Hukum Islam 
Tabel 2.

Jaringan Kantor Individual Islamic Banking Network 2013

\begin{tabular}{clrrr}
\hline Kelompok Bank & $\begin{array}{r}\text { KPO/KC } \\
\text { HOO/BO }\end{array}$ & $\begin{array}{r}\text { KCP/UPS } \\
\text { SBO/SSU }\end{array}$ & $\begin{array}{r}\text { KK } \\
\text { CO }\end{array}$ \\
& & 404 & 1.298 & 224 \\
\hline Bank Umum Syari'ah & 81 & 178 & 119 \\
\hline 1 & PT Bank Syari'ah Muamalat & & & \\
& Indonesia & 136 & 438 & 56 \\
2 & PT Bank Syari'ah Mandiri & 34 & 315 & 6 \\
3 & PT Bank Syari'ah Mega & & & \\
& Indonesia & 11 & 53 & 8 \\
4 & PT Bank Syari'ah BRI & 5 & - & - \\
5 & PT Bank Syari'ah Bukopin & 8 & 6 & - \\
6 & PT Bank Syari'ah Panin & 6 & 6 & 21 \\
7 & PT Bank Syari'ah Victoria & 64 & 170 & 13 \\
8 & PT Bank Syari'ah BCA & 1 & - & - \\
9 & PT Bank Jabar dan Banten & 404 & 1.298 & 224 \\
10 & PT Bank Syari'ah BNI & & & \\
\hline
\end{tabular}

Tabel tersebut di atas menggambaran sebaran dari jaringan bank syari'ah secara individual. Berikut ini juga disampaikan gambaran dari bank umum konvensional yang memiliki unit layanan syari'ah:

Tabel 3.

Jaringan Kantor Individual Islamic Banking Network 2013

\begin{tabular}{rrrrr}
\hline Kelompok Bank & $\begin{array}{r}\text { KPO/KC } \\
\text { HOO/BO }\end{array}$ & $\begin{array}{r}\text { KCP/UPS } \\
\text { SBO/SSU }\end{array}$ & $\begin{array}{c}\text { KK } \\
\text { CO }\end{array}$ \\
\hline Unit Usaha Syari'ah & 166 & 298 & 71 \\
\hline 1 & PT Bank Danamon & 25 & 144 & - \\
2 & PT Bank Permata & 12 & 9 & -
\end{tabular}

${ }^{19}$ Diolah dari Statistik Bank Syari’ah September 2013, Otoritas Jasa Keuangan (OJK) www/ojkgovid.

${ }^{20}$ Diolah dari Statistik Bank Syari'ah September 2013, Otoritas Jasa Keuangan (OJK) www/ojkgov.id. 
Abdul Mujib

\begin{tabular}{clrrr}
3 & PT Bank Internas ional Indones ia & 5 & 21 & - \\
4 & (BII) & & & \\
5 & PT CIMB Niaga & 29 & 4 & - \\
6 & PT Bank DKI & 2 & 8 & 6 \\
7 & BPD DIY Jawa Tengah (Jateng) & 1 & 2 & 5 \\
8 & BPD Jawa Timur (Jatim) & 2 & 3 & 2 \\
9 & BPD Banda Aceh & 1 & 3 & 37 \\
10 & BPD Sumatera Uta ra (Sumut) & 2 & 12 & - \\
11 & BPD Sumatera Barat (Sumbar) & 5 & 3 & - \\
12 & BPD Riau & 3 & 5 & - \\
13 & BPD Sumatera Selatan (Sumsel) & 2 & 5 & - \\
14 & BPD Kal imantan Selatan (Kal sel) & 3 & 1 & 6 \\
15 & BPD Kal imantan Barat (Kalbar) & 2 & - & - \\
16 & BPD Kal imantan Timur (Kal tim) & 1 & 4 & 3 \\
17 & BPD Sulawes i Selatan (Sul sel) & 2 & 12 & 2 \\
18 & BPD Nusa Tenggara Barat (NTB) & 3 & 1 & - \\
19 & PT BTN & 2 & 4 & 1 \\
20 & PT BTPN & 22 & 12 & 1 \\
21 & PT OCBC NISP & 13 & 45 & - \\
22 & PT Bank Sinarmas & 6 & - & - \\
23 & BPD Jambi & 22 & - & 8 \\
\hline & Total & 1 & - & - \\
\hline
\end{tabular}

Data tersebut di atas memberikan gambaran, betapa perkembangan hukum perbankan syari'ah ikut memberikan kontribusi yang cukup signifikan bagi perkembangan kelembagaan dan capaian dana pihak ketiga (DPK) serta peningkatan asset perbankan syari'ah di Indonesia.

\section{Kesimpulan}

Bank syari'ah sebagai salah satu entitas bisnis di Indonesia sudah menunjukkan eksistensinya yang berdeda, namun keberadaan lembaga perbankan syari'ah dapat memberikan satu bentuk layanan bagi masyarakat dan pelaku ekonomi di Indonesia. Dengan dukungan prinsip serta produk yang khas, perbankan syari'ah terbukti mampu bersaing dengan lembaga-lembaga keuangan serupa yang ada di tanah air.

Keberadaan hukum bagi lembaga keuangan syari'ah telah ikut mendorong pertumbuhan lembaga keuangan syari'ah, khususnya perbankan syari'ah. Dari 
data-data yang dipaparkan dalam pembahasan di atas, dapat dikatakan bahwa perkembangan perbankan syari'ah dipengaruhi oleh perkembangan aspek hukum perbankan syari'ah di Indonesia. Perkembangan yang cukup signifikan terjadi pasca lahirnya UU No. 21 Tahun 2008 tentang perbankan, yang secara kelembagaan mencapai angka yang fantastik dan menjangkau hampir di seluruh wilayah tanah air.[a]

\section{DAFTAR PUSTAKA}

A. Karim, Adiwarman, Bank Islam Analisis Fiqh dan Keuangan, Jakarta: Raja Grafindo Persada, 2007.

Anshori, Abdul Ghofur, Perbankan Syari'ah di Indonsia, Yogyakarta: Gajah Mada University Press, 2007.

Deputi Bank Indonesia (BI), Cetak Biru Perkembangan Perbankan Syari'ah Indonesia, Jakarta; Deputi Bank Indonesia (BI), 2003.

Dasuki, H. A. Hafizh, et.al, Ensiklopedi Islam, Jilid I, Jakarta: Ichtiar Baru Van Hoeve, 1994.

Echols, John M., Kamus Inggris Indonesia an English-Indonesia Dictionary, Jakarta: Gramedia Pustaka Utama, 2002.

Frank E Vogel, Islamic Law and Finance Religion, Risk, and Return, Boston: Kluwer Law International, 1998.

Hayes, Samuel L., and Frank E. Vogel, Islamic Law and Finance Religion, Risk, and Return, London: Kluwer Law International, 1998.

Karnaen A. Purwataatmadja, "Peluang dan Strategi Operasional BMI" dalam M. Rusli Karim (ed), Berbagai Aspek Ekonomi Islam, Yogyakarta: Tiara Wacana dan UII, 1992.

Latumaerissa, Julius R., Bank dan Lembaga Keuangan Lainnya, Jakarta: Salemba Empat, 2012.

Lewis, Mervyn K., dkk., Perbankan Syari'ah, edisi Indonesia oleh Burhan Wirasubrata, Jakarta: Serambi, 2003.

Muhammad, (ed), Bank Syari'ah: Analisis Kekuatan, Kelemahan, Peluang dan Ancaman, Yogyakarta: Ekonisia, 2004.

Sumitro, Warkum, Azas-azas Perbankan Islam dan Lembaga-lembaga Terkait, Jakarta: Raja Grafindo Persada, 2004.

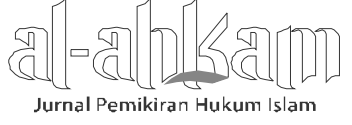

Volume 23, Nomor 2, Oktober 2013 
Abdul Mujib

Venardos, Angelo M., Islamic Banking and Finance in South-East Asia, Its Devalopment and Future, London; World Scientific Publishing, 2005.

Warde, Ibrahim, Islamic Finance in The Global Economy, Edinburgh: Edinburgh University Press, 2000.

182 || Volume 23, Nomor 2, Oktober 2013 